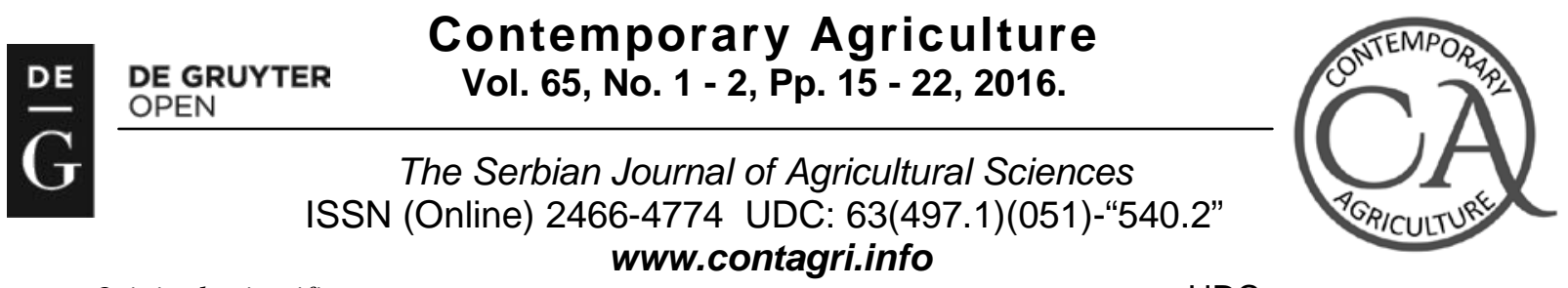

Original scientific paper

UDC: $572.023: 636.5$

DOI: 10.1515/contagri-2016-0003

\title{
FATTY ACID COMPOSITION AND $\beta$-CAROTENE CONTENT IN EGG YOLK OF LAYING HENS FED WITH LINSEED, PAPRIKA AND MARIGOLD
}

\author{
Nedeljka SPASEVSKI*, Dušica ČOLOVIĆ, Slađana RAKITA, Predrag IKONIĆ, Olivera \\ ĐURAGIĆ, Vojislav BANJAC, Đuro VUKMIROVIĆ ${ }^{1}$
}

\begin{abstract}
Summary: Eggs enriched with n-3 fatty acids and natural pigments are desirable in human food chain due to numerous benefits for health. In this study, we investigated the effects of inclusion of co-extruded linseed and sunflower meal into laying hens' diet and replacement of synthesized pigment with paprika and marigold flower as sources of natural pigments. Four hundred 18-wk-old Bovan laying hens divided in two groups (control and experiment) were fed for 12 weeks. Fatty acids and $\beta$ carotene were monitored every fourth week and successively analyzed. Significantly $(p<0.05)$ increased content of $\alpha$-linolenic acid in egg yolk in the experimental group in comparison to the control group was observed with addition of linseed, paprika and marigold in laying hens' nutrition. Nearly the same tendency was observed in eicosapentaenoic acid (EPA) and docosahexaenoic acid (DHA) content. Supplementation of the co-extruded linseed and sunflower meal into laying hens' diet demonstrated significantly $(p<0.05)$ lower $n-6 / n-3$ FA ratio in experimental group compared to control group. The obtained results showed that the synthetic pigment added to laying hens' diet provided better pigmentation of egg yolks after one and two months of the feeding trial than paprika and marigold flower. The concentration of $\beta$-carotene in egg yolks increased in experimental group after three months of the treatment, and that was the first time that concentrations of $\beta$-carotene did not significantly $(p<0.05)$ differ among control and experimental group, which shows that paprika and marigold flower as sources of natural pigments can successfully replace synthetic pigment. We shall continue research in this field with other supplemented mixtures, as there are indices for other potential feed enhancements among oily seeds and herbs.
\end{abstract}

Key words: $\beta$-carotene, fatty acids, egg yolk, linseed, marigold, paprika

\section{INTRODUCTION}

Eggs are recognized as highly nutritious food that has been consumed all over the world. Regardless the fact that eggs contain all essential nutrients, their consumption has been decreased due to the increased public awareness of risk of high cholesterol level. However, according to recent studies there is no strong evidence which confirms the relationship between egg consumption and increase in blood level cholesterol (Lee and Griffin, 2006). It was reported that the content of cholesterol derived from food is much lesser that the cholesterol which is synthesized by humans (Laudadio et al., 2015). In comparison to animal meat, eggs are remarkably beneficial because animal meat contain more fat that can lead to health issues such as heart attack (Simopoulos, 1991). The nutritional profile of eggs can be improved significantly through dietary manipulation. Over the past years, many studies have revealed that the certain feed compounds with important health benefits can be transferred from hens' feed into the egg yolk (Bean and Leeson, 2003; Khan et al., 2012). The eggs nutritional profile can be easily improved by the addition of nutrients such as n-3-fatty acids (FAs), minerals and vitamins.

Consumption of table eggs enriched with highly polyunsaturated fatty acids (PUFA) of the omega-3 series (n-3) can increase the n-3-PUFA content of the human diet. Long chain n-3-PUFAs have demonstrated various positive effects on health, including prevention of cardiovascular diseases, arthritis and diabetes (Simopoulos, 2000). $\alpha$ -

\footnotetext{
${ }^{1}$ Nedeljka Spasevski, MSc, Research Assistant, Dusica Čolović, PhD, Research Associate, Slađana Rakita, MSc, Research Assistant, Predrag Ikonić, PhD, Research Associate, Olivera Đuragić, PhD, Research Associate, Vojislav Banjac MSc, Research Assistant and Đuro Vukmirović PhD, Research Associate. University of Novi Sad,Institute of Food Technology, Bulevar cara Lazara 1, 21000 Novi Sad, Serbia.

*Corresponding author: Nedeljka Spasevski, e-mail: nedeljka.spasevski@fins.uns.ac.rs tel.: + 381214853780.
} 
linolenic acid (ALA, C18:3n-3), eicosapentaenoic acid (EPA, C20:5n-3), and docosahexaenoic acid (DHA, C22:6n3) are recognized as nutritionally important n-3 FAs. ALA is essential FA that cannot be synthesized in the body and therefore, must be derived from the diet (Whelan and Rust, 2006, Čolović et al., 2015a). Since ALA is precursor of EPA and DHA, it can be converted into these FAs which are excreted with the egg yolk afterwards (Ebeid, 2011). Considering that this synthesis process is relatively inefficient in human body, there are the increasing attempts to improve the FA composition of eggs by inclusion of different vegetable sources in hens diet. Among the numerous dietary supplements for laying hens, linseed (Ahmad et al., 2013), fish oil (Kralik et al., 2008) and marine algae (Lemahieu et al. 2013) are reported to contribute successfully to enhancing n-3 PUFA content in egg yolk.

Since a high intake of carotenoid-rich food has manifested numerous health benefits, eggs are considered to be suitable for the transfer of carotenoids into the human food chain (Skřivan and Englmaierová, 2014).The major carotenoid included in the Western diet is $\beta$-carotene which is a provitamin A carotenoid (Stahl and Sies, 2005). Synthetic carotenoids are commonly used for egg yolk coloration; however, alternative natural carotenoid sources have been introduced due to the public concern about the use of synthetic additives. Traditional sources of natural pigments include paprika and marigold flower which have shown to improve yolk color to a greater degree (Lokaewmanee et al., 2011).

The main goal of the present study was to produce eggs with functional properties by inclusion co-extruded linseed and sunflower meal, as a source of omega-3 FAs, as well as paprika and marigold flower, as sources of natural pigments, into laying hens diet.

\section{MATERIAL AND METHOD}

Dietary treatment: The feeding trial was conducted with 400 laying hens (hybrid BOVANS), divided in two groups (control and experiment). The birds were housed in the standard poultry house. The laying hens where aged 18 weeks on the beginning of the experiment. The both groups of hens were fed with complete mixtures which were composed of conventional raw materials, while co-extruded linseed and sunflower meal, paprika and marigold flower were added in the diet for experimental group. Feed and water were provided ad libitum. Ingredients and chemical composition of control and experimental diet were presented in Table 1. Laying hens were fed for twelve weeks and the eggs were collected three times, in one month intervals.

Table 1. Ingredient and chemical composition of the control and experimental diet

\begin{tabular}{|l|c|c|}
\hline \multicolumn{1}{|c|}{ Ingredients (\%) } & Control & Experiment \\
\hline Corn & 54.7 & 54.6 \\
\hline Dehydrated alfalfa meal & 5.0 & 5.0 \\
\hline Sunflower meal & 7.0 & - \\
\hline Co-extruded linenseed and sunflower meal (50:50) & - & 14.0 \\
\hline Soybean full-fat semolina & 17.0 & 10 \\
\hline Soybean meal & 6.3 & 6.0 \\
\hline Monocalcium phosphate & 1.4 & 1.4 \\
\hline Calcium carbonate & 7.3 & 7.3 \\
\hline Sodium chloride & 0.3 & 0.3 \\
\hline Commercial premix* & 1.0 & 1.0 \\
\hline Paprika & - & 0.2 \\
\hline Marigold flower & - & 0.2 \\
\hline & & \\
\hline Moisture & 8.65 & 8.83 \\
\hline Crude ash & 12.99 & 11.69 \\
\hline Crude fat & 6.04 & 6.08 \\
\hline Crude fibre & 4.78 & 4.27 \\
\hline Crude protein & 16.68 & 16.38 \\
\hline
\end{tabular}

* Commercial premix used in the diet for control group contained $0.2 \%$ of synthesized pigment-carophyll red ${ }^{1}$ Control diet contained:(Ca 4.54 \%, P 0.72 \%, Zn 87.40 mg/kg, Fe 337.05 mg/kg, Cu 11.97 mg/kg, Se 0.2 mg/kg, Hg 0.00397 $\mathrm{mg} / \mathrm{kg}, \mathrm{Pb}<2.27 \mathrm{mg} / \mathrm{kg}$, As $<2.27 \mathrm{mg} / \mathrm{kg}, \mathrm{Cd}<0.45 \mathrm{mg} / \mathrm{kg}$ ) 
${ }^{2}$ Experimental diet contained:(Ca 3.83 \%, P 0.48 \%, Zn 88.64 mg/kg, Fe 288.73 mg/kg, Cu 15.86 mg/kg, Se 0.4 mg/kg, Hg $0.00150 \mathrm{mg} / \mathrm{kg}, \mathrm{Pb}<2.33 \mathrm{mg} / \mathrm{kg}$, As $<2.33 \mathrm{mg} / \mathrm{kg}, \mathrm{Cd}<0.47 \mathrm{mg} / \mathrm{kg}$ )

Analysis of fatty acid composition: Lipids were extracted from egg yolk according to Folch method (Folch et al., 1957). FA methyl esters were prepared from the extracted lipids by transmethylation that uses $14 \%$ (w/w) boron trifluoride/methanol solution (Karlović and Andrić, 1996; Ivanov et al., 2012). The obtained samples were analysed by gas chromatography on an Agilent 7890A system (Agilent Technologies, Santa Clara, CA, USA) with a flame ionization detector (GC-FID), autoinjection module for liquid, equipped with fused silica capillary column (Supelco SP-2560 Capillary GC Column $100 \mathrm{~m} \times 0.25 \mathrm{~mm}, \mathrm{~d}=0.20 \mu \mathrm{m}$ ) (Supelco, Bellefonte, USA) and helium as a carrier gas (purity=99.9997 vol \%, flow rate $=1.5 \mathrm{ml} \cdot \mathrm{min}-1$ and pressure=1.092 bar). The GC regime was applied as described in the paper by Čolović et al.(2015b).

$\beta$-carotene analysis: Standard stock solution of $\beta$-carotene (concentration of $6 \mu \mathrm{g} / \mathrm{ml}$ ) was prepared by dissolving $1.5 \mathrm{mg}$ of $\beta$-carotene in $250 \mathrm{ml}$ of acetone. The stock solution was used to prepare following dilutions: $0.6 \mu \mathrm{g} / \mathrm{ml}, 1.2$ $\mu \mathrm{g} / \mathrm{ml}, 1.8 \mu \mathrm{g} / \mathrm{ml}, 2.7 \mu \mathrm{g} / \mathrm{ml}, 3.6 \mu \mathrm{g} / \mathrm{ml}$ and $4.5 \mu \mathrm{g} / \mathrm{ml}$. Absorbance values of standard solutions were read on a spectrophotometer at $450 \mathrm{~nm}$ and the calibration curve was established by plotting the absorbance values versus the corresponding concentrations. Extraction of $\beta$-carotene from egg yolk and determination of $\beta$-carotene was performed according to the method described by Islam (Islam, 2015). In order to obtain smooth paste, $2.5 \mathrm{~g}$ of liquid egg yolk was stired with 1-2 $\mathrm{ml}$ of acetone. Then, the paste was mixed with $50 \mathrm{ml}$ of acetone and filtered through Whatman No.4 filter paper. The filtrate was collected into $100 \mathrm{ml}$ volumetric flask and diluted with acetone. The absorbance was read as soon as possible and the yolk colour was expressed in $\mu \mathrm{g} \beta$-carotene/g sample.

Statistical analysis: The results given in tables are reported as the mean \pm standard deviations (SD). The one-way analysis of variance (ANOVA) was performed to assess data differences between various groups using Statistics software version 12 (Statistica, 2013). Significant differences among treatment means were analyzed by Tukey's HSD tests. The data means were considered different at $p<0.05$.

\section{RESULTS}

Table 2. Fatty acids composition of eggs from laying hens after feeding trial

\begin{tabular}{|c|c|c|c|c|c|c|}
\hline \multirow[t]{2}{*}{ Fatty acid } & \multicolumn{2}{|c|}{ I } & \multicolumn{2}{|c|}{ II } & \multicolumn{2}{|c|}{ III } \\
\hline & Control & Experiment & Control & Experiment & Control & Experiment \\
\hline C14:0 & $0.36 \pm 0.09^{\mathrm{a}}$ & $0.24 \pm 0.07^{\mathrm{a}}$ & $0.34 \pm 0.24^{\mathrm{a}}$ & $0.23 \pm 0.00^{\mathrm{a}}$ & $0.24 \pm 0.02^{\mathrm{a}}$ & $0.20 \pm 0.01^{\mathrm{a}}$ \\
\hline C16:0 & $24.04 \pm 0.88^{\mathrm{a}}$ & $18.46 \pm 0.40^{\mathrm{a}}$ & $21.02 \pm 14.86^{\mathrm{a}}$ & $20.49 \pm 0.62^{\mathrm{a}}$ & $21.71 \pm 0.28^{\mathrm{a}}$ & $19.59 \pm 0.12^{\mathrm{a}}$ \\
\hline C16:1 & $2.89 \pm 0.68^{\mathrm{a}}$ & $1.43 \pm 0.26^{\mathrm{a}}$ & $1.35 \pm 0.96^{\mathrm{a}}$ & $1.77 \pm 0.01^{\mathrm{a}}$ & $1.91 \pm 0.50^{\mathrm{a}}$ & $1.90 \pm 0.01^{\mathrm{a}}$ \\
\hline C18:0 & $8.97 \pm 0.34^{\mathrm{a}}$ & $8.91 \pm 1.75^{\mathrm{a}}$ & $10.03 \pm 7.09^{\mathrm{a}}$ & $9.57 \pm 0.24^{\mathrm{a}}$ & $8.92 \pm 0.86^{\mathrm{a}}$ & $8.82 \pm 1.27^{\mathrm{a}}$ \\
\hline C18:1n-9 & $39.17 \pm 0.71^{\mathrm{a}}$ & $37.79 \pm 3.72^{\mathrm{a}}$ & $34.64 \pm 24.49^{\mathrm{a}}$ & $36.17 \pm 2.10^{\mathrm{a}}$ & $36.67 \pm 2.69^{\mathrm{a}}$ & $40.45 \pm 1.57^{\mathrm{a}}$ \\
\hline C18:2n-6 & $17.92 \pm 0.11^{\mathrm{a}}$ & $22.14 \pm 0.51^{\mathrm{a}}$ & $25.13 \pm 17.77^{\mathrm{a}}$ & $21.34 \pm 1.36^{\mathrm{a}}$ & $23.97 \pm 1.15^{\mathrm{a}}$ & $20.34 \pm 1.29^{\mathrm{a}}$ \\
\hline C18:3n-6 & $0.29 \pm 0.03$ & 1 & $0.28 \pm 0.20$ & 1 & $0.21 \pm 0.18$ & 1 \\
\hline C18:3n-3 & $1.03 \pm 0.04^{\mathrm{a}}$ & $5.48 \pm 0.67^{\mathrm{b}}$ & $1.67 \pm 1.18^{\mathrm{a}}$ & $4.68 \pm 0.28^{\mathrm{b}}$ & $1.45 \pm 0.02^{\mathrm{a}}$ & $4.30 \pm 0.40^{\mathrm{b}}$ \\
\hline C20:2 & $0.39 \pm 0.00^{\mathrm{a}}$ & $0.40 \pm 0.10^{\mathrm{a}}$ & $0.55 \pm 0.39^{\mathrm{a}}$ & $0.34 \pm 0.00^{\mathrm{a}}$ & $0.48 \pm 0.11^{\mathrm{a}}$ & $0.30 \pm 0.00^{\mathrm{a}}$ \\
\hline C20:3n-6 & $0.32 \pm 0.01^{\mathrm{a}}$ & $0.29 \pm 0.04^{\mathrm{a}}$ & $0.36 \pm 0.26^{\mathrm{a}}$ & $0.35 \pm 0.00^{\mathrm{a}}$ & $0.31 \pm 0.05^{\mathrm{a}}$ & $0.29 \pm 0.01^{\mathrm{a}}$ \\
\hline C20:3n-3 & $0.03 \pm 0.01^{\mathrm{a}}$ & $0.26 \pm 0.11^{\mathrm{a}}$ & $0.07 \pm 0.05^{\mathrm{a}}$ & $0.15 \pm 0.02^{\mathrm{a}}$ & $0.15 \pm 0.14^{\mathrm{a}}$ & $0.13 \pm 0.01^{\mathrm{a}}$ \\
\hline C23:0 & $3.18 \pm 0.15^{\mathrm{a}}$ & $2.12 \pm 0.83^{\mathrm{a}}$ & $2.99 \pm 2.12^{\mathrm{a}}$ & $2.18 \pm 0.07^{\mathrm{a}}$ & $2.76 \pm 0.92^{\mathrm{a}}$ & $1.77 \pm 0.36^{\mathrm{a}}$ \\
\hline$C 20: 5 n-3$ & $0.05 \pm 0.00^{\mathrm{a}}$ & $0.18 \pm 0.02^{\mathrm{b}}$ & $0.05 \pm 0.03^{\mathrm{a}}$ & $0.17 \pm 0.01^{\mathrm{b}}$ & $0.04 \pm 0.00^{\mathrm{a}}$ & $0.13 \pm 0.06^{\mathrm{b}}$ \\
\hline C22:6n-3 & $1.35 \pm 0.24^{\mathrm{a}}$ & $2.28 \pm 0.97^{\mathrm{b}}$ & $1.51 \pm 1.07^{\mathrm{a}}$ & $2.30 \pm 0.07^{\mathrm{b}}$ & $1.18 \pm 0.51^{\mathrm{a}}$ & $1.78 \pm 0.65^{\mathrm{b}}$ \\
\hline SFA & 36.56 & 29.74 & 34.38 & 32.47 & 33.63 & 30.38 \\
\hline MUFA & 42.06 & 39.23 & 35.99 & 37.95 & 38.79 & 42.34 \\
\hline PUFA & 21.09 & 31.03 & 29.34 & 29.32 & 27.58 & 27.28 \\
\hline
\end{tabular}

The results are presented as mean $\pm S D ; n=3$ 
I, II and III- first, second and third month of feeding trial, SFA- saturated fatty acids; MUFA-monounsaturated fatty acid; PUFApolyunsaturated fatty acid

Different superscript letter between certain FA content of experimental and control group within the same feeding period indicate statistically significant differences $(p<0.05)$

Table 2 presents the FAs profile of the egg yolks of laying hens from control and the group fed withn-3 enriched diet. According to presented results it could be observed that the FA compositions of the yolk lipids were influenced by the experimental diets. The major effects of the diet were observed in FAs ALA, EPA and DHA. As it was expected, the addition of linseed in hens' diet resulted in increased content of ALA which was from approx. 2.8 to 4.8 times higher in experimental group in comparison with control group. EPA content in experimental group was more than three times higher in experimental than in control group, while DHA content in experimental group increased approx. 1.5 times.

Looking further at Table 2, it can be noticed that SFA content egg yolk lipids of experimental group significantly decreased $(p=0.03)$ in comparison with control group for all feeding periods. Even though a slight increase in the content of PUFA was noticed, significant changes in the content of MUFA and PUFA in yolk lipids were not detected $(p>0.05)$.

Figure 1 shows changes in total n-3 and n-6 FAs in control and experimental diet with duration of feeding period.

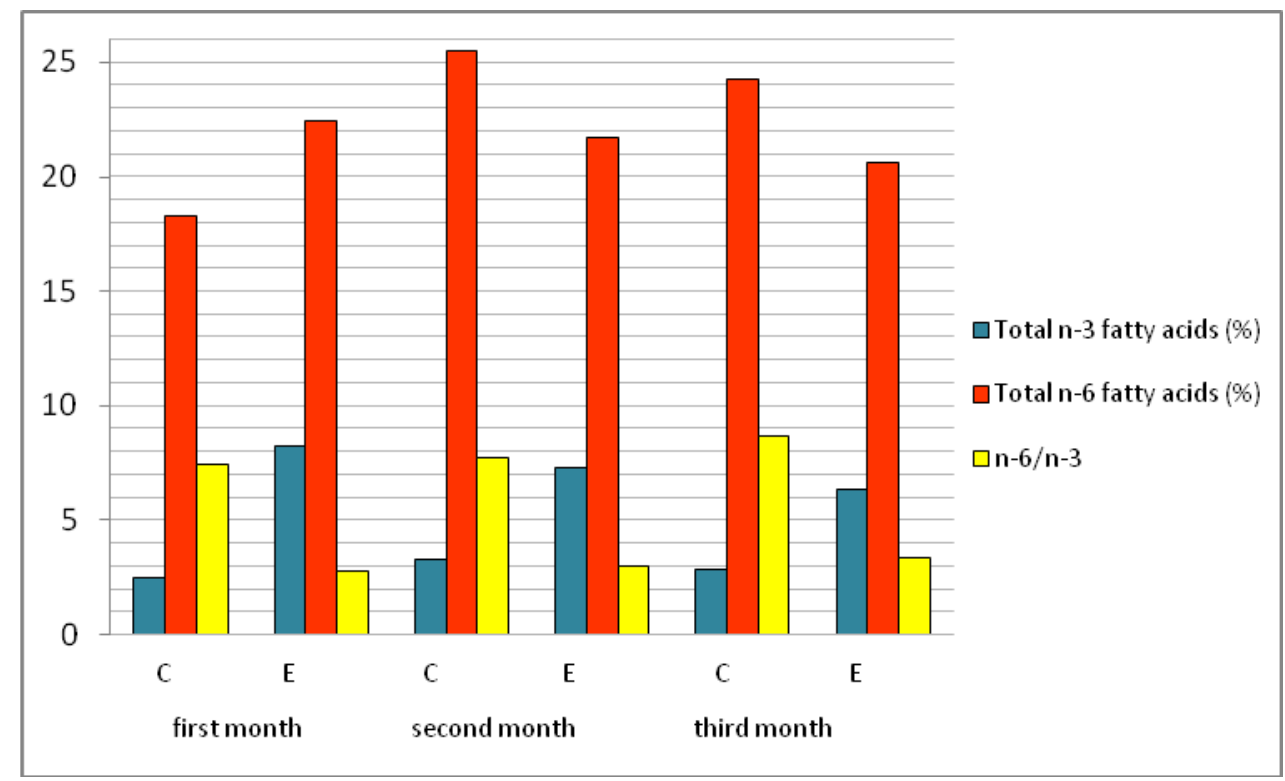

Figure 1.Changes in total $n-3$ and $n-6$ fatty acid content

(C - control group, $\mathrm{E}$ - experimental group)

Content of total n-6 FAs was remarkably higher in all samples in comparison with total n-3, which is in accordance with literature data. What is more important is that total n-3 FA content significantly increased $(\mathrm{p}<0.001)$ in all experimental samples in comparison with control group. Also, the addition of co-extruded linseed and sunflower meal to the hens' diet caused significant decrease in n-6/n-3 ratio $(p<0.005)$. In experimental group n6/n-3 ratio was lower than 4 for every duration of feeding period, while in control group the ratio was higher than 7 . Figure 2 presents content of $\beta$-carotene in egg yolk of laying hens ( $\mu \mathrm{g} / \mathrm{g}$ egg yolk) in control and experimental group. 


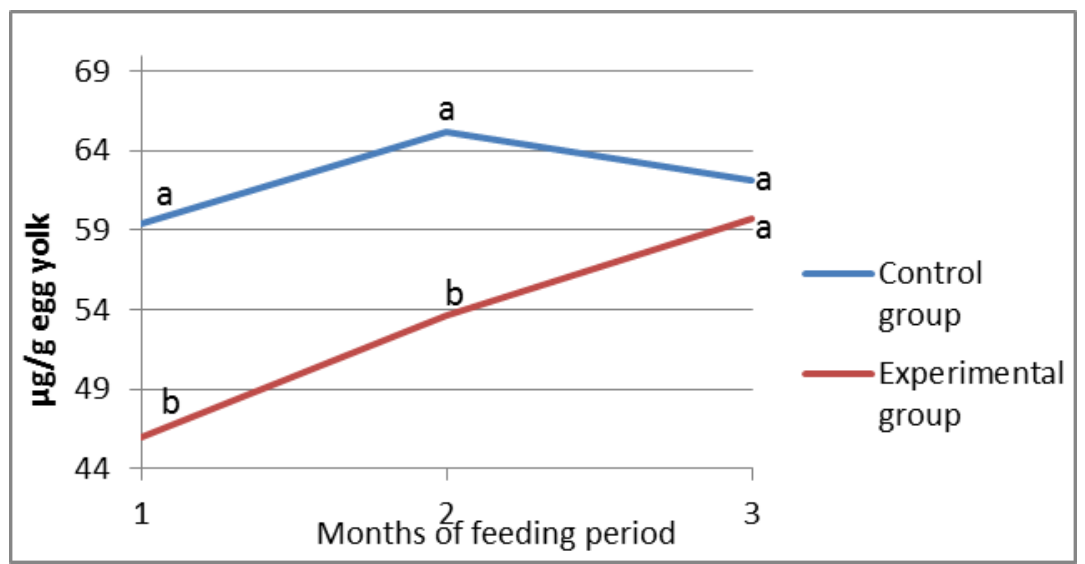

Figure 2.Content of $\beta$-carotene in egg yolk of laying hens $(\mu \mathrm{g} / \mathrm{g}$ egg yolk)

(Different letters within the control and experimental group within the same feeding period indicate statistically significant difference at $\mathrm{p}<0.05$ )

The obtained results showed that the synthetic pigment added to laying hens' diet provided better pigmentation of egg yolks after one and two months of the feeding trial than paprika and marigold flower. The concentration of $\beta$ carotene in egg yolks increased in experimental group after three months of the treatment, and that was the first time that concentrations of $\beta$-carotene did not significantly $(p<0.05)$ differ among control and experimental groups.

\section{DISCUSSION}

It has already been known that the increasing levels of ALA from different vegetable fat sources lead to the increase in their content in the yolk lipid. In the research of Sari et al. (2002), dietary supplementation with different levels of linseed (0, 5, 10 and 15\%) caused the increase in the concentration of ALA, EPA and DHA. In our study, the total content of n-3 FAs in experimental eggs enhanced in comparison to control eggs. Lewis et al. (2000) found that the inclusion of $7 \%$ linseed oil in a control diet increased n-3 PUFA content $1.2 \%$ to $7.8 \%$ in the egg yolk, while ALA content increased 30 times. Dalle Zotte et al. (2015) also reported that the supplementation of extruded and grounded linseed to hen diets resulted in changed composition of FAs in enriched eggs compared to standard eggs, and that change resulted in increased content of desirable n-3 PUFA content. In addition, a significant decrease in the total content of SFA in egg yolks from hens fed with the experiment diet was observed, which is desirable with respect to human health. The obtained results are in compliance with Oliveira et al. (2010) who reported that the egg yolks of hens fed diets containing different vegetable sources (soybean, sunflower and linseed oil) showed lower percentages of saturated FAs than the yolks of hens fed the control diet.

The balance between n-6 and n-3 PUFA is very important criteria for proper human nutrition. Being aware of n-3 PUFA benefits and health promoting effects, the nutritionists recommend a diet rich in n-3 fatty acids, as well as a lower n-6/n-3 ratio from the currently common 15-20:1 to 1-4:1 (Gebauer et al., 2006, Čolović et al., 2012). According to Simopoulos (2000) and Kralik (2008), the ratio of n-6/n-3 PUFA in egg yolk lipids less than 4:1 is considered to be beneficial to human health. The desirable ratio of n-6/n-3 PUFA was stated by other authors (Ebeid 2011) who included both linseed and fish oil to laying hens' diet. As already mentioned, n-6/n-3 ratio was lower than 4 in experimental group for all feeding trial periods in our experiment.

$\beta$-carotene is such an active molecule with desirable health-connected properties, which are related to its antioxidant power in inactivating certain reactive oxygen species, such as singlet oxygen. That is why the demand for this carotene, as an additive in cosmetics and for functional food applications, is growing. For functional foods, heatprocessing causes a significant effect on the stability and bioactivity of $\beta$-carotene and certain studies show that these parameters are dependent on its origin (Phan-Thí et al., 2016). Natural $\beta$-carotene consists of two isomers: all-trans and 9-cis and is present only in natural environments, whereas synthetic $\beta$-carotene contains only the all-trans isomer, which has lower liposolubility and lower antioxidant property than 9-cis isomer. Epidemiological evidences have shown that $\beta$-carotene can prevent cancer of various organs such as: lungs, stomach, cervix, pancreas, colon, rectum, breast, prostate and ovary by means of its antioxidant activity (Jayappriyan et al., 2013). Our results confirmed that, by using natural sources of $\beta$-carotene, almost the same content of this provitamine in egg yolk can be achieved. As reported by Karadas et al. (2006), concentration of total carotenoid in egg yolks, treated with $2 \%$ alfalfa was $22.48 \pm 0.77 \mu \mathrm{g} / \mathrm{g}$ egg yolk and for treatment with $0.2 \%$ marigold was $39.01 \pm 1.50 \mu \mathrm{g} / \mathrm{g}$ egg yolk. In this 
study was shown that we can effectively replace synthetic pigments with natural carotenoids from paprika and marigold flower, because almost the same effect was achieved after three months period of feeding. Since benefits from natural pigments are numerous, synthetic pigments can be excluded from laying hens diet.

\section{CONCLUSION}

Eggs of laying hens are excellent source of high biological value protein, vitamins, FAs and mineral. The carotenoids are important antioxidants and contribute significantly to the body's defence against free radical attack and hence to its ability to counteract any disease process. Modification of diet hens can change the FA profile and increase the proportion of functional ingredients in eggs. The advantages of simultaneous enrichment of eggs with linen seed and carotenoids (from paprika and marigold flowers), include increase content of ALA, EPA and DHA in egg yolk, better stability PUFAs, high availability nutrients such as carotenoids, an improved antioxidant and n-3 status people which consume these eggs. We can replace synthetic pigment with natural sources on adequate way by feeding laying hen with paprika and marigold flower.

\section{ACKNOWLEDGMENT}

The experiment presented in this paper is a part of Project no. 114-451-796/2015 by Provincial secretariat for science and technological development of Vojvodina and a part of an Integrated Interdisciplinary Research Project number III 46012, funded by Serbian Ministry of Education, Science and Technological Development. Authors also thank to dr. Dejan Delibašić for remarkable help in design of the experiment

\section{REFERENCES}

AHMAD, S., YOUSAF, M., KAMRAN, Z., SOHAIL, M.U: Effect of feeding whole linseed as a source of polyunsaturated fatty acids on performance and egg characteristics of laying hens kept at high ambient temperature. Brazilian Journal of Poultry Science, 15(1): 21-26, 2013.

BEAN .Dand LEESON S: Long-term effects of feeding flaxseed on performance and egg fatty acid composition of brown and white hens. Poultry Science, 82:388-394, 2003.

ČOLOVIĆ D, BERENJI J, LEVART A, SALOBIR J, LEVIĆ J, ČOLOVIĆ R, POPOVIĆ S: Fatty acid composition and natural antioxidant capacity of ten Serbian linseed cultivars. Food and Feed Research, 42 (2): 139-146, 2015 a.

ČOLOVIĆ D, LEVIĆ J, ČABARKAPA I, ČOLOVIĆ R, LEVIĆ LJ, SEDEJ I: Stability of an extruded, linseed based functional feed additive with the suplementation of vitamin E and carvacrol. Journal of Animal and Feed Sciences 24:349-358, 2015b.

ČOLOVIĆ D, ILIĆ N, OKANOVIĆ Đ, PALIĆ D: Heat treatment effect on fatty acid composition in different pig tissues. Food and Feed Research 39 (2): 89-96, 2012.

DALLE ZOTTE A, ANDRIGHETTO I, GIACCONE V, MARCHESINI G:Dietary enrichment of n-3 PUFA for laying hens: effect of different sources on production, composition and quality of eggs. Animal Science Papers and Reports, 33(4): 411-424, 2015.

EBEID TA: The impact of incorporation of n-3 fatty acids into eggs on ovarian follicular development, immune response, antioxidative status and tibial bone characteristics in aged laying hens. Animal, 5(10): 1554-1562, 2011.

FOLCH J, LEES M, SLOANE STANLEY GH:A simple method for the isolation and purification of total lipides from animal tissues. J. Bilo. Chem. 226(1),497-509, 1957.

GEBAUER SK, PSOTA TL, HARRIS WS, KRIS-ETHERTON PM: n-3 Fatty acid dietary recommendations and food sources to achieve essentiality and cardiovascular benefits. American Journal of Clinical Nutrition, 83(suppl): 1526-1535, 2006.

ISLAM K.M.S., SCHWEIGERT F.J:Comparison of three spectrophotometric methods for analysis of egg yolk carotenoids.Food Chemistry, 172, 233-237, 2015.

IVANOV D., COLOVIC, R., LEVIC, J., SREDANOVIC, S: Optimization of supercritical fluid extraction of linseed oil using RSM. European Journal of Lipid Science and Technology, 114: 807-815, 2012.

JAYAPPRIYAN KR, RAJKUMAR R., VENKATAKRISHNAN V, NAGARAJ S, RENGASAMY R: In vitro anticancer activity of natural $\beta$-carotene from Dunaliella salina EU5891199 in PC-3 cells. Biomedicine and Preventive Nutrition 3: 99-105, 2013.

KARADAS F, GRAMMENIDIS E, SURAI PF, ACAMOVIC T AND SPARKS NHC: Effects of carotenoids from lucerne, marigold and tomato on egg yolk pigmentation and carotenoid composition. British Poultry Science Volume 47, Number 5, pp. 561-566, 2006.

KARLOVIĆ Đ, ANDRIĆ N. Kontrola kvaliteta semena uljarica. Tehnolos`ki fakultet Novi Sad, Savezni zavod za standardizaciju, Beograd (Serbia), 1996.

KHAN RU, NAZ S, NIKOUSEFAT Z, TUFARELLI V, JAVDANI M, QURESHI MS, AND LAUDADIO V: Potential applications of ginger (Zingiber officinale) in poultry diets. World's Poultry Science Journal, 68: 245-252, 2012.

KRALIK G, ŠKRTIĆ Z, SUCHÝ P, STRAKOVÁ E, GAJČEVIĆ Z: Feeding fish oil and linseed oil to laying hens to increase the n-3 PUFA of egg yolk. Acta Veterinaria Brno, 77:561-568, 2008. 
LAUDADIO V, LORUSSO V, LASTELLA NMB, DHAMA K, KARTHIK K, TIWARI R, ALAM GM, TUFARELLI V: Enhancement of Nutraceutical Value of Table Eggs Through Poultry Feeding Strategies. International Journal of Pharmacology, 11: 201-212, 2015.

LEE A AND GRIFFIN B: Dietary cholesterol, eggs and coronary heart disease risk in perspective. A review.British Nutrition Foundation Nutrition Bulletin, 31, 21-27, 2006.

LEMAHIEU C, BRUNEEL C, TERMOTE-VERHALLEA R, MUYLAERTC K, BUYSEB J, FOUBERTA I: Impact of feed supplementation with different omega-3 rich microalgae species on enrichment of eggs of laying hens. Food Chemistry, 141(4), 4051-4059, 2013.

LEWIS NM, SEBURG S, FLANAGAN NL: Enriched eggs as a source of n-3 polyunsaturated fatty acids for humans. Poultry Science, 79:971-974, 2000.

LOKAEWMANEE K, YAMAUCHI K, KOMORI T, SAITO K: Enhancement of yolk color in raw and boiled egg yolk with lutein from marigold flower meal and marigold flower extract. The Journal of Poultry Science, 48(1): 25-32, 2011.

OLIVEIRA DD, BAIAO NC, CANCADO SV, GRIMALDI R., SOUZA MR, LARA LJC, LANA AMQ: Effects of lipid sources in the diet of laying hens on fattyacid profiles of egg yolks. Poultry Science, 89:2484-2490, 2010.

PHAN-THI H, DURANDP, PROST M, PROSTE, WACHÉ Y: Effect of heat-processing on the antioxidant and prooxidant activities of $\beta$-carotene from natural and synthetic origins on red blood cells. Food Chemistry 190 (1), 1137-1144, 2016.

SARI M, AKȘIT H, ÖZDO ĞAN M, BASMACIO ĞLU H: Effect of addition of flaxseed to diets of laying hens on some production characteristics, levels of yolk and serum cholesterol, and fatty acid composition of yolk. Arch Geflugelkd, 66:75-79, 2002.

SKRIVAN M, ENGLMAIEROVA M: The deposition of carotenoids and $\alpha$-tocopherol in hen eggs produced under a combination of sequential feeding and grazing. Animal Feed Science and Technology, 190:79-86, 2014.

SIMOPOULOS AP:Omega-3 fatty acids in health and disease and in growth and development. The American Journal of Clinical Nutrition, 54:438-463, 1991.

SIMOPOULOS AP: Human requirement for n-3 polyunsaturated fatty acids. Poultry Science, 79:961-970, 2000.

STAHL W, SIES H: Bioactivity and protective effects of natural carotenoids. Biochimica et Biophysica Acta, 1740:101-107, 2005.

WHELAN J and RUST C: Innovative dietary sources of n-3 fatty acids. Annual Review of Nutrition, 26:75-103, 2006. 


\title{
SASTAV MASNIH KISELINA ISADRŽAJ $\beta$-KAROTENA U ŽUMANCETU KOKA NOSILJA HRANJENIH SA LANENIM SEMENOM, PAPRIKOM I NEVENOM
}

\author{
Nedeljka SPASEVSKI, Dušica ČOLOVIĆ, Slađana RAKITA, Predrag IKONIĆ, Olivera ĐURAGIĆ, \\ Vojislav BANJAC, Đuro VUKMIROVIĆ
}

Izvod: Jaja obogaćena sa n -3 masnim kiselinama i prirodnim pigmentima su poželjni u lancu ljudske ishrane zbog brojnih pogodnosti za zdravlje. U ovoj studiji, ispitivali smo efekte dodavanja ko-ekstrudiranog lanenog semena i suncokretove sačme u ishranu koka nosilja i zamenu sintetičkog pigmenta sa paprikom i cvetom nevena kao izvorima prirodnih pigmenata.Četiri stotine Bovan koka nosilja, starih 18 nedelja, podeljenih u dve grupe kontrolnu i eksperimentalnu, hranjene su tokom 12 nedelja. Masne kiseline i $\beta$-karoten su praćeni svake četvrtenedelje i odmah analizirane. Sadržaj linolenske kiseline značajno je povećan $\quad(p<0,05)$ u žumancetu u eksperimentalnoj grupi (kojoj je dodato ekstrudirano laneno seme, paprika i nevena) u odnosu na kontrolnu grupu. Slična tendencija je primećena u sadržaju eikosapentaenoične kiseline (EPA) i dokozaheksaenske kiseline (DHA). Dodatak ko-ekstrudiranog lanenog semena i suncokretove sačme u hranu koka nosilja značajno $(p<0,05)$ smanjuje $n$ 6/n-3 odnos masnih kiselina u eksperimentalnoj grupi u odnosu na kontrolnu grupu. Sintetički pigment u hrani koka nosilja dao je bolju pigmentaciju žumanceta nakon prvog i drugog meseca hranjenja u odnosu na eksperimentalnu grupu koka nosilja koje su hranjene sa dodatkom paprike i cveta nevena. Koncentracija $\beta$-karotena u žumancetu se povećala u eksperimentalnoj grupi posle tri meseca tretmana i nije se značajno razlikovala $(p<0,05)$ u kontrolnoj i eksperimentalnoj grupi, čime je pokazano da se dodatkom paprike i cveta nevena može veoma uspešno zameniti upotreba sintetičkih pigmenata u ishrani koka nosilja. Mi ćemo nastaviti istra živanja u ovoj oblasti sa drugim dodacima smeša, jer postoje pokazatelji za druge potencijalne izvore među uljaricama i lekovitim biljkama.

Ključne reči: masne kiseline, $\beta$-karoten, žumance, laneno seme

Received / Primljen: 13.04.2016.

Accepted / Prihvaćen: 02.06.2016. 